\title{
Epidemiology of COVID-19: Implications for a Gastroenterologist
}

\author{
Vishal Sharma ${ }^{1, \odot} \quad$ Usha Dutta $^{1}$ \\ ${ }^{1}$ Department of Gastroenterology, Postgraduate Institute of \\ Medical Education and Research, Chandigarh, India
}

J Digest Endosc 2020;11:8-12
It is unclear whether the current novel coronavirus disease 2019 (COVID-19) global pandemic brought to our doorsteps has zoonotic origins from some bats or has origins in some laboratory. However, it is mandatory for us to be aware of the rapid scientific developments in this field to tackle this problem effectively. In this issue, Chowdhury and Oommen have highlighted the epidemiology, transmission dynamics, and the clinical spectrum of COVID-19 infection. ${ }^{1}$ The present editorial will focus on the implications and lessons that gastroenterologists need to learn from the epidemiology and transmission dynamics of severe acute respiratory syndrome-cronavirus-2 (SARS-CoV-2). Gastroenterologists are faced with a unique situation that they must enter precisely the area in which the virus is thriving, namely, the throat of the infected patient with their endoscopes, without maintaining social distancing, and come out unscathed. The gastroenterologists must be prepared to handle the situation arising out of spread of this virus which has high infectivity, could transmit from asymptomatic individuals, and has a prolonged infectivity which is spreading in a population with virtually no herd immunity. ${ }^{1}$ In India, there is a steady rise in number of cases, though we have managed to flatten the curve to some extent due to lock down rightly imposed by our government in contrast to other countries, where delay resulted in a steep curve.

\section{Epidemiology}

Both the avatars of COVID-19 infection, symptomatic and asymptomatic, pose a problem for us. This virus has high transmissibility with an R0 is 2 to 3, that is, each person, especially if symptomatic is likely to spread the infection to 2 to 3 additional persons. A high index of suspicion, early detection, establishing rapid diagnosis and prompt isolation is of paramount importance to reduce spread within a health care system. Health care workers are at increased risk

DOI https://doi.org/ 10.1055/s-0040-1712549 ISSN 0976-5042.
Address for correspondence Usha Dutta MD, DM, Department of Gastroenterology, Postgraduate Institute of Medical Education and Research, Chandigarh 160012, India (e-mail: ushadutta@gmail.com).

for acquiring this infection and protecting them is important for any health care system. Also, preventing a health care worker from spreading infection amongst other employees is also of importance. So, all staff should be asked to report to their administration if they have any symptoms/contact with potential patient and they should self-quarantine themselves at home. Those who are at high risk for adverse outcome, such as those with diabetes, cardiovascular diseases, chronic respiratory diseases, hypertension, those on immunosuppression, those with malignancy, or serious medical illnesses, should preferably not be brought in for front line duty. Those with elderly parents/family members at home should be explained to ensure standard hygiene practices at home when they come back from hospital duty. There are increasing instances now, of a wave of quarantining of a large number of staff who have come in contact with an asymptomatic health care worker who has tested positive. This significantly reduces working hands in a health care system and jeopardizes the system during this pandemic. Asymptomatic COVID-19 infection also needs identification and appropriate isolation or else it would result in transmission to our team, contaminate our environment, as well as infect our other patients. There are concerns, even after antibodies develop, the infection could recur, adding a further challenge. Present diagnostic methods are time consuming, expensive, and have substantial false negativity. Further, to add to the tribulations, the viral shedding in the feces is now well recognized, although the infectivity is uncertain as of now.

\section{Implications of Mode of Transmission of SARS-COV2}

The main mode of transmission remains droplet-borne infection directly or indirectly through fomites. Thus, patients coming in face-to-face contact with a gastroenterologist are likely to transmit the virus. Universal masking and social distancing should be the norm. During endoscopy, since social

(C2020 Society of Gastrointestinal Endoscopy of India

\section{License terms}

(우 (1) $\Theta \circledast$ 
distancing cannot be maintained and there is high likelihood of aerosol transmission, special precautions should be taken at all times. Universal precautions should again be the norm. Also, decontamination of the endoscopy room, Out Patients Department (OPD) area, and inpatient area will be necessary to reduce transmission to other patients and health care workers. Moreover, studies have shown that the viral RNA and protein have been detected also in the feces. It is still unclear if this "viral shedding" can result in fecooral transmission. ${ }^{2}$ However, till the time the dust settles over this concern, gastroenterologists should take abundant precautions for safe colonoscopy and consider feces as possibly infectious. Also, appropriate decontamination of washrooms used by COVID-19-positive patients, prevention of aerosol contamination during colonoscopy need attention. There are also concerns of prolonged shedding of the virus in the feces which could mean that patients may still be infectious even after negative nasopharyngeal testing. ${ }^{3}$ Although, this is not, deemed as particularly important, the patients are being discharged into the community after negative testing from the oropharyngeal swabs alone. Further, virus could be detected in sewage and can last long at low temperatures raising concerns of possible fecooral transmission, especially in regions where hygiene and piped water supply are concerns. ${ }^{4}$ Also, since health care workers can carry this virus back home on their sleeves, they should shed their hospital clothes and shower before they come in contact with their family members. Preferably, health care workers, should work in their hospital scrubs when they are in hospital area. Also, clean areas and possibly contaminated areas should be demarcated within workplaces and daily cleaning/disinfection practices should be put in place to reduce fomite transmission.

\section{Gastrointestinal and Hepatic Manifestations}

Although primarily recognized as a respiratory illness, there is a growing recognition of the involvement of the gastrointestinal (GI) tract with manifestations like diarrhea, abdominal pain and GI bleeding, and liver in the form of mild hepatitis. The virus engages with the angiotensin-converting enzyme 2 (ACE-2) and transmembrane serine protease 2 (TMPRSS2) for entry into the host cells. These receptors are, expressed in GI tissues including esophagus, ileum colon, biliary duct, and the liver. ${ }^{5}$

It is also well recognized now that mild elevations of liver enzymes are common in COVID-19. The elevations are typically in the aminotransferases and occasional reports also suggest elevations in gamma-glutamyl transferase (GGT). Some reports also suggest that the frequency and the amount of elevations in liver enzymes may be higher in patients with severe disease. There are only occasional reports of clinical presentation with acute hepatitis, and very high (>10 ULN) transaminasemia is uncommon. Although the mechanisms causing hepatic injury are yet to be unravelled, the contributing factors could be direct viral toxicity, immune injury, ischemic hepatitis, and drug-induced liver injury. ${ }^{6}$ We should remember to, however, exclude other causes of hepatitis such as other viral hepatitis, as well as drug-induced hepatitis.

\section{Impact on Course of Preexisting Gastrointestinal Illnesses}

One remarkable feature of this pandemic has been a deluge of information and publications on the topic which needs a good understanding of evidence-based medicine for appropriate interpretation. Many studies are observational, quasirandomized, or have inadequate sample size and hence have inadequate validity and reliability to make too many generalizations. Another feature has been that practice guidelines have been released on management of patients with various chronic GI and liver diseases without sufficient data to back it. The course and therapy of patients with inflammatory bowel disease, chronic liver diseases, autoimmune diseases, and those requiring repeated endoscopic interventions are likely to be altered in the face of this infection. Though data from China does not indicate any heightened risk of COVID-19 in patients with Inflammatory Bowel Disease (IBD), many guidelines warn against use of high-dose steroids, especially $>20 \mathrm{mg} /$ day, suggest shifting patients from infliximab infusion to adalimumab subcutaneous self-administered injection to avoid health care visits, use noninvasive markers to assess disease activity other than endoscopy and withdraw/minimize use of biologicals. ${ }^{7}$ Since vast majority of Indian patients with IBD are not on biologicals, IBD should be treated with primarily mesalamine which has been found to be safe, oral budesonide with minimal use of systemic steroids. In patients who are in remission, there is no need to change therapy.

However, the emphasis should be laid on protective measures like social distancing, hand hygiene, and food hygiene in all patients with IBD. In cases of documented COVID-19 infection, steroids or other immunosuppression should be withheld. Clinicians should be wary of COVID-19 infection masquerading as exacerbation of IBD because diarrhea could be a manifestation of COVID-19 infection. Teleconsultations are likely to help patients with chronic illness to manage their disease without bringing them into the hospitals. Similar concerns may also apply to other disease, like severe alcoholic hepatitis or autoimmune hepatitis, which require steroids or immunosuppression. Moreover, liver transplantation has decreased worldwide in the setting of this pandemic, resulting delay in providing definitive therapy for patients with acute and chronic liver failure.

\section{Impact on Clinical Consultations}

Perhaps the most significant impact of the COVID-19 pandemic has been the global disruption of various health care services, mainly outpatient's services. This has been primarily because of evidence that health care services and institutions could serve as hotspots for spread of this viral illness. Many health care professionals have been infected and lost lives globally. Since the first principal of medicine is 
"Primum Non Nocere," institutions have responded by shutting routine services like OPDs. This has brought to focus the urgent need for alternative mechanisms to provide advice and care including social media platforms, telephonic advice, and use of telemedicine.

Responding to the challenge, telemedicine practice guidelines have been issued by the Board of Governors (substituting the Medical Council of India) in conjunction with Niti Ayog. ${ }^{8}$ These guidelines enable the provision of telemedicine consultations by registered medical practitioners using various platforms like telephone, mobile phones, videos, use of internet, WhatsApp, Facebook Messenger. etc., or mobile phone application or internet-based digital platforms, Skype, e-mail, etc. There are certain issues with these consults like patient identification, ensuring privacy, absence of real-time interaction, possibility of imposters, and issues of documentation and lack of rapport with the patients, and absence of clinical examination. While the use of these platforms may be appropriate in the current scenario, soon the organizations will have prepare for reopening their services and will need many issues to be addressed. The issues which need to be discussed prior to reopening services are suggested in - Table 1.

\section{Impact on Endoscopy Services}

Various societies have suggested that only emergency and urgent procedures can be done during the period when COVID-19 outbreak is a concern and till the times the endoscopy suites and staff are prepared to undertake routine procedures. ${ }^{9-11}$ This means that all routine procedures and screening endoscopies be postponed. While doing emergency endoscopies, and since testing may not be available at a short notice, it is better that all endoscopies be done using complete personal protective equipment with N95 masks, goggles, full waterresistant gowns, head caps, and shoe covers. Ensuring additional protection for face using transparent glass shields is a simple, low cost-effective way to reduce transmission risk when worn over a mask. It is also a useful practice to wear a routine surgical mask over the N95 to reduce contamination of the N95 mask, since N95 masks must be worn for longer periods due to cost and availability issues. The surgical mask can be discarded after each procedure. Disinfection of the endoscopy room, especially of the surfaces should be routine after each procedure. It is best to consider the possibility of ultraviolet (UV) irradiation and or ozone treatment, if possible. Restarting of routine endoscopy should be gradual after taking into consideration issues like testing of patients and staff and implementation of appropriate precautions (-Table $\mathbf{1}$ ). This is important because of concerns of aerosol generation and also possibility of fecooral transmission of SARS-CoV-2.

\section{Impact on Training of Gastrointestinal Residents/Fellows}

The COVID-19 pandemic has taken a huge toll on the residents, as well as their training program. The disruption has affected their morale and increased instances of burnout are being reported. The faculty and trainers need to help the residents through this. At the authors' institution, the endoscopies are only being done by consultants at the present time. The pandemic has also resulted in disruption of resident training as classes have been postponed and endoscopies restricted. However, use of social media and digital platforms may allow online classes to be conducted and thereby minimize the disruption. Organizations need to adapt these measures to ensure that COVID-19 does not majorly affects resident training. Consideration must also be given to the use of GI mentor or other similar simulators to ensure that endoscopy training is also affected as little as is possible. Exam system will need modification, as well as postponement, for those due to complete their training period.

\section{Impact on Ongoing Research and Clinical Trials}

Since most clinical trials need mandated clinical visits and assessment, it is best to put such trials on hold. Further, new patient recruitment during the period of ongoing COVID-19 pandemic has suffered and is likely to delay most ongoing studies. The need to continue a trial should be decided on an individual basis, but it is certain that clinical trials and research in non-COVID-19 will be impacted adversely because of the need to limit nonessential visits and to maintain physical distancing. Therefore, ongoing trials will be impacted by limitations on patient follow-up. The researchers may utilize the time better to complete pending papers, and pen new projects for sunnier times.

\section{Preparing for the Future}

COVID-19 has challenged the current health care systems in many ways and the systems will have to adapt to these changes. The end result will be a new normal, telemedicine use might increase, and so will the use of online teaching and training on simulators. Endoscopy is likely to have significant improvements and one hopes that the result will be much safer suites and practices for both the caregivers and the patients. Also, the most everlasting impact could be on how we see our patients: social distancing could be the new normal, use of clinical examination could decline with increased use of noninvasive, no touch techniques. The only way forward is to convert this challenge into an opportunity to transform the way we provide a "safe" care to our patients. Developing countries have additional challenges to meet due to socioeconomic issues, overcrowding, poor health care systems, poor educational status, inadequate personal protective equipments, and overall poorer infrastructure. Until we develop herd immunity or put a vaccination system is in place, we are susceptible to COVID-19 infection, thus mandating us to take all due precautions to prevent transmission, morbidity, and mortality due to COVID-19 virus.

\section{Conflict of Interest}

None declared. 
Table 1 Patient care in COVID-19 era: lessons from epidemiology

\begin{tabular}{|c|c|}
\hline \multicolumn{2}{|r|}{ Outpatient visits } \\
\hline Issues & Possible solutions \\
\hline \multicolumn{2}{|l|}{ Patient related } \\
\hline $\begin{array}{l}\text { - Should all patients be tested for } \\
\text { COVID-19? }\end{array}$ & $\begin{array}{l}\text { Preferably yes. All to be screened with temperature assessment, screening questionnaire. } \\
\text { COVID testing in all versus suspects only, should be based on local resources. }\end{array}$ \\
\hline - Which tests to use? & $\begin{array}{l}\text { PCR testing is the currently most accepted method. It has } 8 \text { hours turnaround time } \\
\text { minimum. Gene Xpert test has turnaround of }<1 \text { hour. } \\
\text { Antibody test for patient, has limited utility presently. }\end{array}$ \\
\hline $\begin{array}{l}\text { - Should visitors be allowed with } \\
\text { patients? }\end{array}$ & No, minimize attendants \\
\hline $\begin{array}{l}\text { - Should mask use be made } \\
\text { mandatory? }\end{array}$ & Yes, universal masks may help in reducing risk of transmission \\
\hline - How to manage the visiting hours? & $\begin{array}{l}\text { Appointment system with slotting to minimize holding time for a patient in the health } \\
\text { care institution }\end{array}$ \\
\hline $\begin{array}{l}\text { - How to reduce patient contact } \\
\text { time? }\end{array}$ & $\begin{array}{l}\text { Prior detailed assessment using telemedicine followed by brief face to face visit only for } \\
\text { examination purposes only if required. }\end{array}$ \\
\hline \multicolumn{2}{|l|}{ Care giver related } \\
\hline - Should care providers be tested? & $\begin{array}{l}\text { Yes, as infection may be asymptomatic and transmission from health care provider may } \\
\text { affect large numbers }\end{array}$ \\
\hline $\begin{array}{l}\text { - If so, which tests and how } \\
\text { frequently? }\end{array}$ & $\begin{array}{l}\text { Combination of tests may be considered. PCR based tests for diagnosis of active infection } \\
\text { and antibody test for showing prior exposure }\end{array}$ \\
\hline - What PPE is to be worn? & Possibly triple layer masks, gloves, and apron with a face shield \\
\hline \multicolumn{2}{|l|}{ Setting related } \\
\hline Room & Well ventilated. Avoid using central air-conditioning \\
\hline - Wash basin & Running water with elbow operated taps and liquid soap dispensers \\
\hline - Social distance & Mark patient area and care giver area to make social distancing mandatory. \\
\hline - To notify patients about their turn & Use public address system or computerized/digital display boards. \\
\hline - Items in the OPD room & $\begin{array}{l}\text { Examination gloves, hand-sanitizer, stationery and disposal bins. Use transparent } \\
\text { plastic covers to reduce direct fomite contact. Keep surface disinfecting agents to clean } \\
\text { potentially infected surfaces. }\end{array}$ \\
\hline - Waiting area & $\begin{array}{l}\text { Place chairs in such a way that social distancing becomes mandatory. Keep only } \\
\text { restricted number of chairs in the waiting area. }\end{array}$ \\
\hline \multicolumn{2}{|r|}{ Endoscopy } \\
\hline \multicolumn{2}{|l|}{ Patient related } \\
\hline $\begin{array}{l}\text { - What preprocedure assessment be } \\
\text { done }\end{array}$ & $\begin{array}{l}\text { Need for endoscopy, underlying symptoms of COVID-19, and screening tests/ } \\
\text { temperature screening be considered }\end{array}$ \\
\hline $\begin{array}{l}\text { - Should every patient be endoscoped } \\
\text { under sedation or anesthesia? }\end{array}$ & $\begin{array}{l}\text { General anesthesia may be preferred if testing not available to minimize aerosol } \\
\text { contamination of the suite. }\end{array}$ \\
\hline \multicolumn{2}{|l|}{ Caregiver-related } \\
\hline - Should glass/visor barrier be used? & $\begin{array}{l}\text { As endoscopy is an aerosol generating procedures, may be better to place the patient in } \\
\text { a transparent plastic box designed for endoscopy. }\end{array}$ \\
\hline What PPE should be used? & $\begin{array}{l}\text { In absence of testing it is better to use N95 masks and full PPE with water resistant gown, } \\
\text { and double gloves. Even with testing (considering possible false negatives) universal } \\
\text { precautions are preferable }\end{array}$ \\
\hline $\begin{array}{l}\text { How many individuals be there in } \\
\text { endoscopy? }\end{array}$ & $\begin{array}{l}\text { Best to keep only essential staff. At this stage, it may better if trainees are not performing } \\
\text { the procedures. Single team should complete entire session comprising of one senior } \\
\text { endoscopist, one technician and one endoscopy assistant. }\end{array}$ \\
\hline Any other issues? & Staff be trained in donning and doffing and appropriate use of PPE \\
\hline
\end{tabular}


Table 1 (Continued)

\begin{tabular}{|l|l|}
\hline \multicolumn{2}{|l|}{ Setting related } \\
\hline $\begin{array}{l}\text { What sort of suites be used for } \\
\text { endoscopy? }\end{array}$ & $\begin{array}{l}\text { Negative pressure rooms, especially for endoscopy services, are likely to reduce transmis- } \\
\text { sion. Creation of separate donning and doffing areas should be done }\end{array}$ \\
\hline $\begin{array}{l}\text { How many procedures should be } \\
\text { done? }\end{array}$ & $\begin{array}{l}\text { Better to limit the number of procedures to allow for disinfection of endoscopes and } \\
\text { environment between the procedures. It is unclear what should be time difference } \\
\text { between two procedures, but in suites which do not have a negative pressure rooms, } \\
\text { 1-hour difference should be considered }\end{array}$ \\
\hline How should endoscopes be handled? & $\begin{array}{l}\text { Some changes in the manner of doing endoscopy with hand holding the scope tilted } \\
\text { down, so that it is further from the endoscopist's face. The knob and handling area may } \\
\text { be covered with plastic sheet to reduce aerosol generation }\end{array}$ \\
\hline
\end{tabular}

Abbreviations: COVID-19, novel coronavirus disease 2019; PCR, polymerase chain reaction; PPE, personal protective equipment.

\section{References}

1 Chowdhury SD, Oommen AM. Epidemiology of COVID-19. J Dig Endosc 2020;11;3-7

2 Gu J, Han B, Wang J. COVID-19: gastrointestinal manifestations and potential fecal-oral transmission. Gastroenterology 2020;(e-pub ahead of print). doi 10.1053/j.gastro.2020.02.054

$3 \mathrm{Wu}$ Y, Guo C, Tang L, et al. Prolonged presence of SARS-CoV-2 viral RNA in faecal samples. Lancet Gastroenterol Hepatol 2020;5(5):434-435

4 Wang XW, Li J, Guo T, et al. Concentration and detection of SARS coronavirus in sewage from Xiao Tang Shan Hospital and the 309th Hospital of the Chinese People's Liberation Army. Water Sci Technol 2005;52(8):213-221

5 Zhang H, Kang Z, Gong H, et al. Digestive system is a potential route of COVID-19: an analysis of single-cell coexpression pattern of key proteins in viral entry process. BMJGut 2020; doi 10.1136/gutjnl-2020-320953

6 Zhang C, Shi L, Wang FS. Liver injury in COVID-19: management and challenges. Lancet Gastroenterol Hepatol 2020;5(5): 428-430
7 Monteleone G, Ardizzone S. Are patients with inflammatory bowel disease at increased risk for COVID-19 infection? J Crohn's Colitis 2020;(e-pub ahead of print). doi 10.1093/ ecco-jcc/jjaa061

8 Board of Governors Medical Council of India. Telemedicine Practice Guidelines. Available at https://www.mohfw.gov.in/ pdf/Telemedicine.pdf. Accessed April 22, 2020

9 Chiu PWY, Ng SC, Inoue H, et al. Practice of endoscopy during COVID-19 pandemic: position statements of the Asian Pacific Society for Digestive Endoscopy (APSDE-COVID statements) BMJGut 2020;doi 10.1136/gutjnl-2020-321185

10 Sultan S, Lim JK, Altayar O, et al; AGA. AGA institute rapid recommendations for gastrointestinal procedures during the COVID-19 pandemic. Gastroenterology 2020; (e-pub ahead of print) doi 10.1053/j.gastro.2020.03.072

11 Repici A, Maselli R, Colombo M, et al. Coronavirus (COVID-19) outbreak: what the department of endoscopy should know. Gastrointest Endosc 2020;(e-pub ahead of print) doi 10.1016/j. gie.2020.03.019 